\title{
Hippocampal Heterotopia Lack Functional Kv4.2 Potassium Channels in the Methylazoxymethanol Model of Cortical Malformations and Epilepsy
}

\author{
Peter A. Castro, ${ }^{1}$ Edward C. Cooper, ${ }^{2,3}$ Daniel H. Lowenstein, ${ }^{5}$ and Scott C. Baraban ${ }^{1,4}$ \\ Departments of ${ }^{1}$ Neurological Surgery, ${ }^{2}$ Neurology, and ${ }^{3}$ Physiology, and ${ }^{4}$ The Graduate Program in Neuroscience, \\ University of California, San Francisco, San Francisco, California 94143, and ${ }^{5}$ Department of Neurology, Beth Israel \\ Deaconess Medical Center, Harvard Medical School, Boston, Massachusetts 02115
}

Human cortical malformations often result in severe forms of epilepsy. Although the morphological properties of cells within these malformations are well characterized, very little is known about the function of these cells. In rats, prenatal methylazoxymethanol (MAM) exposure produces distinct nodules of disorganized pyramidal-like neurons (e.g., nodular heterotopia) and loss of lamination in cortical and hippocampal structures. Hippocampal nodular heterotopias are prone to hyperexcitability and may contribute to the increased seizure susceptibility observed in these animals. Here we demonstrate that heterotopic pyramidal neurons in the hippocampus fail to express a potassium channel subunit corresponding to the fast, transient A-type current. In situ hybridization and immunohistochemical analysis revealed markedly reduced expression of Kv4.2 (Atype) channel subunits in heterotopic cell regions of the hip- pocampus of MAM-exposed rats. Patch-clamp recordings from visualized heterotopic neurons indicated a lack of fast, transient $\left(I_{A}\right)$-type potassium current and hyperexcitable firing. A-type currents were observed on normotopic pyramidal neurons in MAM-exposed rats and on interneurons, CA1 pyramidal neurons, and cortical layer $\mathrm{V}-\mathrm{VI}$ pyramidal neurons in salinetreated control rats. Changes in A-current were not associated with an alteration in the function or expression of delayed, rectifier (Kv2.1) potassium channels on heterotopic cells. We conclude that heterotopic neurons lack functional A-type Kv4.2 potassium channels and that this abnormality could contribute to the increased excitability and decreased seizure thresholds associated with brain malformations in MAM-exposed rats.

Key words: epilepsy; dysplasia; heterotopia; hippocampus; patch-clamp; potassium channel
Cortical malformations are often associated with human developmental delay, schizophrenia, and severe forms of epilepsy (Scheibel and Conrad, 1993; Aicardi, 1994; Dubeau et al., 1995; Palmini, 2000). Because malformations are characterized by neurons that differentiate in abnormal positions, they are believed to result from a developmental neuronal migration disorder. With improvements in neuroimaging technology, disorders of brain development are now identified with increasing frequency in epileptic patients (Kuzniecky, 1994; Mischel et al., 1995; Chan et al., 1998). For example, cortical malformations are detected in nearly $20 \%$ of all patients, and the incidence of these malformations rises to $>40 \%$ in patients who have undergone surgery for medically refractory seizures (Duchowny et al., 1992; Annegers, 1994; Brannstrom et al., 1996). Malformation-associated epilepsy syndromes in humans include, but are not limited to, clusters of disorganized cells (nodular heterotopia) in type II lissencephaly, loss of sulci in Miller-Dieker lissencephaly, and abnormal neuronal orientation with loss of lamination in Taylor-type cortical dysplasia (Whiting and Duchowny, 1999; Andermann, 2000).

Received April 9, 2001; revised June 11, 2001; accepted June 14, 2001.

This work was supported by funds from the Sandler Family Supporting Foundation, Epilepsy Foundation of America, Lucile Packard Children's Health Initiative, March of Dimes Foundation (S.C.B.), and the National Institutes of Health (D.H.L.). We thank members of the Baraban laboratory for comments on earlier versions of this manuscript, Samuel Pleasure, Jack Parent, Anil Baghri, and Anthony Kim for help with in situ hybridizations, and H. J. Wenzel for assistance with biocytin cell fills. E.C.C. thanks Lily and Y. N. Jan for space and support.

Correspondence should be addressed to S. C. Baraban, Box 0520, Department of Neurological Surgery, University of California, San Francisco, 513 Parnassus Avenue, San Francisco, CA 94143. E-mail: baraban@itsa.ucsf.edu.

Copyright (ㄷ) 2001 Society for Neuroscience $0270-6474 / 01 / 216626-09 \$ 15.00 / 0$
Epileptic seizures associated with these malformations are often severe and resistant to anticonvulsant drugs. Although clinical studies suggest that malformed brain regions are sites of seizure generation and surgical removal of abnormally organized tissue can result in the cessation of seizures (Palmini et al., 1991a,b, 1995; Aicardi, 1994), very little is known about the molecular and electrophysiological properties of neurons within a cortical malformation (Yurkewicz et al., 1984).

In rodents, prenatal injection of methylazoxymethanol (MAM), a DNA methylating agent, induces a characteristic pattern of disorganization in the cerebral cortex and hippocampus, with loss of lamination and distinct nodular heterotopia (Singh, 1977; Baraban and Schwartzkroin, 1995; Chevassus-au-Louis et al., 1998a). Hippocampal nodular heterotopias in these animals contain pyramidal-like neurons that receive excessive catecholaminergic innervation, exhibit vascular abnormalities, and display aberrant glutamate receptor expression (Johnston et al., 1979; Bardosi et al., 1987; Rafiki et al., 1998). These anatomical abnormalities are similar, in many respects, to those observed in brain tissue obtained from children with malformation-associated epilepsies (Trottier et al., 1994; Babb et al., 1998). Independent efforts by Germano and colleagues (Germano et al., 1996; Germano and Sperber, 1997), Ben-Ari and colleagues (Chevassusau-Louis et al., 1998a), and our laboratory (Baraban and Schwartzkroin, 1996) have revealed an increased propensity for the development of seizure activity in MAM-exposed animals using a wide variety of seizure induction protocols (e.g., hyperthermia, kindling, kainate, or flurothyl). The enhanced seizure susceptibility of MAM rats may be related to hippocampal hy- 
perexcitability because in vitro studies demonstrated independent seizure generation in isolated hippocampal nodular heterotopia (Baraban et al., 2000). Although there is much evidence to suggest that malformed brain regions in the MAM model contribute to the generation of seizure activity, the specific cellular and/or molecular mechanism(s) that could result in hyperexcitability remain poorly understood.

Given that potassium channels play critical roles in modulating neuronal excitability (Pongs, 1999) and mutations in $\mathrm{K}^{+}$channels can result in epileptic phenotypes (Biervert et al., 1998; Singh et al., 1998; Smart et al., 1998; Cooper and Jan, 1999; Zuberi et al., 1999), we explored the possibility that heterotopic neurons might exhibit $\mathrm{K}^{+}$channel abnormalities. Our approach used a combination of anatomical methods to determine patterns of $\mathrm{K}^{+}$channel expression, and patch-clamp techniques to study whole-cell $\mathrm{K}^{+}$current function and firing activity for visualized heterotopic neurons in hippocampal slices from MAM-exposed rats. We report that heterotopic neurons, in the MAM model of cortical malformations and epilepsy, exhibit markedly reduced expression of a specific potassium channel subunit (Kv4.2), resulting in loss of fast, transient $\left(I_{\mathrm{A}}\right)$-type voltage-activated $\mathrm{K}^{+}$current and hyperexcitable neuronal firing.

\section{MATERIALS AND METHODS}

Prenatal methylazoxymethanol injection. Pregnant Sprague Dawley rats were injected with either $0.9 \%$ physiological saline or $25 \mathrm{mg} / \mathrm{kg}$ methylazoxymethanol acetate (NCI Chemical Carcinogen, Kansas City, MO). Intraperitoneal injections $(0.3 \mathrm{ml}, 15 \%$ DMSO $)$ were made on day 15 of gestation. All animal care and use conformed to the NIH Guide for Care and Use of Laboratory Animals and were approved by the University of California, San Francisco Committee on Animal Research.

In situ hybridization. For detection of ion channel transcripts, unique antisense oligonucleotides were synthesized based on published gene information. Sense and antisense digoxigenin-labeled RNA probes were transcribed with $\mathrm{T} 7$ poylmerase, and the yields of both probes were quantified using a spectrophotometer. For preparation of hippocampal sections, rat brains were removed from animals perfused with chilled $4 \%$ paraformaldehyde, cryoprotected (in $30 \%$ sucrose solution), frozen rapidly on dry ice, and cut into $14 \mu \mathrm{m}$ sections. Sections were thaw-mounted onto silanated glass slides and post-fixed in $4 \%$ paraformaldehyde $(1 \mathrm{hr})$. Tissue sections were then treated with $1 \mathrm{mg} / \mathrm{ml}$ proteinase $\mathrm{K}$ and $0.25 \%$ acetic acid in $0.1 \mathrm{~m}$ triethanolamine, $\mathrm{pH} 8.0(10 \mathrm{~min})$. Sections were prehybridized $(2-4 \mathrm{hr})$ at $65^{\circ} \mathrm{C}$ in hybridization buffer $(50 \%$ deionized formamide, $5 \times$ SSC, $100 \mu \mathrm{g} / \mathrm{ml}$ heparin, $1 \times$ Denhardt's solution, $0.1 \%$ Tween $20,0.1 \%$ CHAPS, $5 \mathrm{~mm}$ EDTA, and $300 \mathrm{mg} / \mathrm{ml}$ yeast tRNA, $\mathrm{pH}$ 7.4) and hybridized at $65^{\circ} \mathrm{C}(16-20 \mathrm{hr})$ in the same buffer with $\sim 1 \mathrm{ng} / \mathrm{ml}$ riboprobe. Sections were then washed three times in high stringency $0.2 \times$ $\mathrm{SSC}$ at $65^{\circ} \mathrm{C}$. After washing at room temperature in PBT $(1 \times \mathrm{PBS}, 2$ $\mathrm{mg} / \mathrm{ml} \mathrm{BSA}, 0.1 \%$ Triton X-100), sections were blocked in $20 \%$ lambs serum in PBT $(1 \mathrm{hr})$ and incubated with sheep anti-digoxigenin Fab fragments conjugated with PBT in blocking solution $(4 \mathrm{hr})$. Sections were washed in PBT followed by alkaline phosphatase. The antibodyconjugated alkaline phosphatase was visualized by reaction with 4-nitroblue tetrazolium chloride and 5-bromo-4-chloro 3-indolylphosphate in the presence of Levamisole. The color reaction was stopped with TE buffer (10 mM Tris-Cl, 1 mm EDTA, $\mathrm{pH} 8.0$ ); tissue was fixed in $4 \%$ formaldehyde for $2 \mathrm{hr}$. Slides were coverslipped with Aquamount.

Immunohistochemistry. Tissue preparation, incubations, and immunofluorescence microscopy were performed as described previously (Cooper et al., 1998). In brief, after perfusion with $4 \%$ freshly prepared paraformaldehyde, brains were dissected, post-fixed, and washed in PBS. Floating sections $(50 \mu \mathrm{m})$ were cut using a vibrating microtome (Leica). Sections were permeabilized with $0.4 \%$ Triton X-100 in TBS $(50 \mathrm{~mm}$ Tris, $100 \mathrm{~mm} \mathrm{NaCl}$ ) for $30 \mathrm{~min}$. All subsequent steps were performed with TBS, $0.2 \%$ Triton X-100 (TBST), with additions as indicated. Sections were blocked with 5\% normal goat serum (NGS) in TBST for 1 $\mathrm{hr}$, then primary antibodies were added directly to the sections in blocking solution and incubated for 15-18 hr. After washing with TBST for $90 \mathrm{~min}$ (five changes), sections were incubated with biotinylated goat anti-rabbit IgG (Vector Labs, Burlingame, CA; 1:200) for $2 \mathrm{hr}$ in
TBST $/ 5 \%$ NGS. After washing, sections were incubated with streptavadin-Cy2 (Molecular Probes, Eugene, OR; 1:500) in TBST/5\% NGS for $2 \mathrm{hr}$. Sections were washed as before, incubated with $1 \mu \mathrm{g} / \mathrm{ml}$ propidium iodide in TBS, washed in TBS, and mounted in ProLong (Molecular Probes). Sections were examined either using a Bio-Rad 1024 confocal microscope or a Nikon E800 epifluorescence microscope equipped with a SPOT cooled charge-coupled device camera.

Electrophysiology. Rat pups [postnatal day (P)10-20] were anesthetized with Nembutal and decapitated. Brains were removed rapidly and chilled in ice-cold, oxygenated $\left(95 \% \mathrm{O}_{2}, 5 \% \mathrm{CO}_{2}\right)$ sucrose artificial CSF (sACSF) consisting of (in mM): 220 sucrose, $3 \mathrm{KCl}, 1.25 \mathrm{NaH}_{2} \mathrm{PO}_{4}, 1.2$ $\mathrm{MgSO}_{4}, 26 \mathrm{NaCO}_{3}, 2 \mathrm{CaCl}_{2}$, and 10 dextrose (295-300 mOsm). The brain was then blocked and glued to the stage of a vibrating tissue slicer (Campden Instruments), and 300- $\mu$ m-thick slices were cut in ice-cold, oxygenated SACSF. Resulting slices were then transferred to a holding chamber where they remained submerged in oxygenated normal ACSF (nACSF) consisting of (in mM): $124 \mathrm{NaCl}, 3 \mathrm{KCl}, 1.25 \mathrm{NaH}_{2} \mathrm{PO}_{4}, 26$ $\mathrm{NaCO}_{3}, 1.2 \mathrm{MgSO}_{4}, 2 \mathrm{CaCl}_{2}$, and 10 dextrose (295-300 mOsm). Slices were held at $37^{\circ} \mathrm{C}$ for $30 \mathrm{~min}$ and then stored at room temperature (1-6 $\mathrm{hr}$ ). For recordings, individual slices were transferred to a submersiontype recording chamber and perfused with oxygenated nACSF at 33$35^{\circ} \mathrm{C}$. In voltage-clamp studies, nACSF was supplemented with a $\mathrm{Na}^{+}$ channel antagonist (tetrodotoxin, $0.5-1 \mu \mathrm{M}$ ) and $100 \mu \mathrm{M} \mathrm{CdCl}_{2}$ to block voltage-activated $\mathrm{Ca}^{2+}$ channels. Conventional whole-cell patch-pipette recordings were obtained from visually identified neurons using an infrared differential interference contrast (IR-DIC) video microscopy system (Stuart et al., 1993). Patch electrodes (3-6 M $\Omega$ ) were pulled from borosilicate glass capillary tubing and coated with Sylgard (Dow Chemical). Intracellular patch-pipette solution for whole-cell voltage-clamp recordings contained (in $\mathrm{mM}$ ): $140 \mathrm{KMeGluconate,} 2 \mathrm{MgCl}_{2}, 2 \mathrm{CaCl}_{2}, 10$ HEPES, 10 EGTA, 2 Mg-ATP, $0.2 \mathrm{Na}_{3}$-GTP, pH 7.2 (285-290 mOsm); for whole-cell current-clamp recordings the pipette solution contained (in $\mathrm{mM}$ ): $120 \mathrm{KMeGluconate,} 10 \mathrm{KCl}, 1 \mathrm{MgCl}_{2}, 0.025 \mathrm{CaCl}_{2}, 10 \mathrm{HEPES}$, 0.2 EGTA, $2 \mathrm{Mg}$-ATP, $0.2 \mathrm{Na}_{3}$-GTP, pH 7.2 (285-290 mOsm). In some recordings, the marker biocytin (1\%; Sigma, St. Louis, MO) was included in the patch pipette to permit post hoc identification of physiologically characterized cells (Williams et al., 1994). Current and voltage were recorded with an Axopatch 1D amplifier (Axon Instruments) and monitored on an oscilloscope; voltage-step commands were delivered to the amplifier from a Pentium computer using pCLAMP software (Axon). Whole-cell voltage-clamp data were filtered at $2 \mathrm{kHz}$. Series resistance and holding current were carefully monitored, and cells were discarded if either value changed by $>20 \%$. $I_{\mathrm{K}}$ and $I_{\mathrm{A}}$ were recorded at a holding potential of $-60 \mathrm{mV}$ and evoked by $600 \mathrm{msec}$ depolarizing steps (after a brief prepulse to $-115 \mathrm{mV}$ ) between -80 and $+20 \mathrm{mV}$.

\section{RESULTS}

Prenatal treatment with MAM induced distinct cortical and hippocampal malformations in offspring, as reported previously (Singh, 1977; Chevassus-au-Louis et al., 1998b,c; Baraban et al., 2000). Cortical thinning and nodular heterotopia in the CA1CA2 region of hippocampus are hallmark features of MAMexposed rat brains and were observed in all animals studied $(n=$ 46). Hippocampal heterotopia were observed as early as $\mathrm{P} 3$ and persisted for the lifetime of the animal (Fig. 1A). For electrophysiological studies, patch-clamp recordings were obtained from pyramidal-like cells within hippocampal heterotopia under IRDIC visualization (Fig. $1 B, C$ ). A small number of cells within hippocampal heterotopia could be described as large $(>20 \mu \mathrm{m})$, round interneurons. These cells exhibited the fast-spiking and sharp post-spike afterhyperpolarization firing patterns typical of GABAergic interneurons (Williams et al., 1994). Initially, heterotopic cell identity was confirmed post hoc via biocytin labeling (Fig. 1B).

\section{Potassium channel expression in heterotopic neurons}

The Kv2.1 (Shab) and Kv4.2 (Shal) potassium channel subunits are widely expressed in rat hippocampus, with prominent staining in the cell bodies and dendrites of dentate granule cells and CA1-CA3 pyramidal cells (Sheng et al., 1992; Maletic-Savatic et 

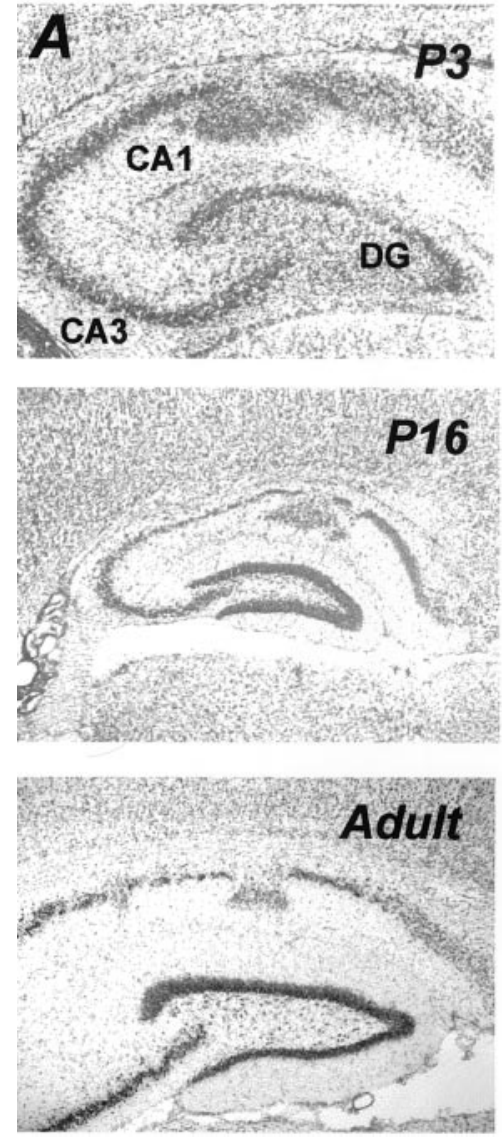

B
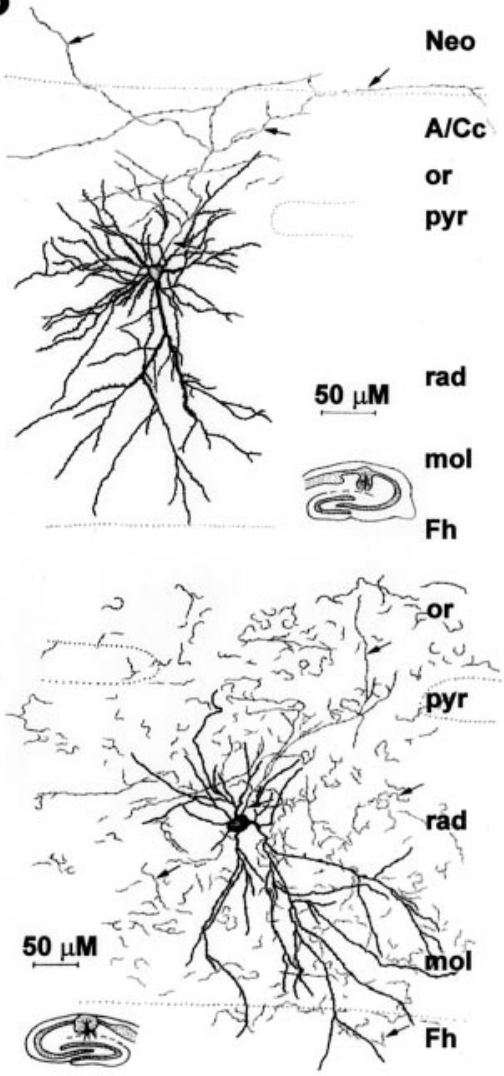

C

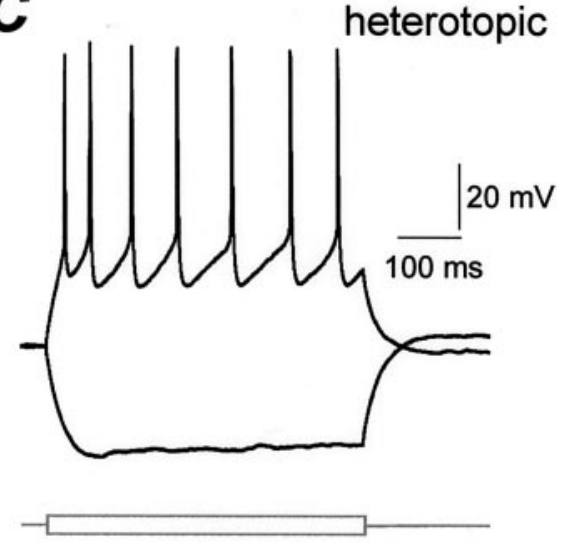

interneuron

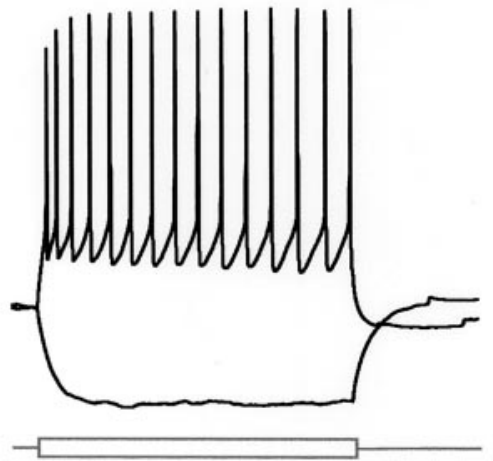

Figure 1. Hippocampi from MAM-exposed rats. $A$, These representative examples illustrate the appearance of heterotopic cell clusters within the CA1 pyramidal cell region of the hippocampal formation. Coronal sections (30 $\mu \mathrm{m}$ thick) were stained with cresyl violet. Cell clusters (or nodular heterotopia) were found at $P 3, P 16$, and P60+ (Adult). $C A 1, C A 3$, Hippocampal subfields; $D G$, dentate gyrus. $B$, These representative biocytin-filled cells illustrate the appearance and dendritic arborization of heterotopic pyramidal-like (top) and interneuron-like (bottom) cells. Note the presence of dendritic spines on heterotopic pyramidal-like neurons and a neocortical axonal projection (arrow). Schematics of the heterotopic slice are shown in the inset. $C$, Representative current-clamp traces from the biocytin-filled neurons shown in $B$.

al., 1995; Serodio and Rudy, 1998). In heterologous cells, channels formed by Kv4.2 subunits mediate fast, transient $\left(I_{\mathrm{A}}\right.$-type) $\mathrm{K}^{+}$ currents, and Kv2.1 subunits mediate sustained delayed, rectifier ( $I_{\mathrm{K}}$-type) potassium currents. To determine whether these potassium channel subunits are present in the malformed hippocampus of MAM-exposed rats, mRNA expression patterns were examined using digoxigenin-labeled riboprobes. Experiments using hippocampal sections from saline-treated control rats established that Shal (Kv4.2)- and Shab (Kv2.1)-type potassium channel subunits are prominently expressed in the CA1 pyramidal cell region of hippocampus, as expected (Fig. 2A,D). In sections from MAM-exposed rats, strong hybridization signal for Kv4.2 was observed in normotopic pyramidal cells (e.g., CA1 cells within the malformed hippocampus that do not cluster into nodules). However, Kv4.2 mRNA levels were extremely low in regions of hippocampus containing nodular heterotopia (Dubeau et al., 1995; Du et al., 1998; Murakoshi and Trimmer, 1999) (Fig. 2B,C). In contrast, Kv2.1 potassium channels were prominently expressed throughout the hippocampus of MAM-exposed rats. Figure $2 E$ shows the distribution of mRNA for Kv2.1 in a representative hippocampal section containing a nodular heterotopia. Note that Kv2.1 probes label pyramidal neurons in both normotopic and heterotopic cell regions of MAM-exposed rat hippocampus (Fig. 2F).

To confirm that observed reductions in Kv4.2 message were associated with a corresponding reduction in channel protein, immunohistochemical studies were performed using an antibody to Kv4.2 (Sheng et al., 1992). In the CA1 region of sections from control animals, Kv4.2 immunoreactivity was detected in stratum (st.) pyramidale and was particularly dense in stratum radiatum, st. lacunosum-moleculare, and st. oriens, where the pyramidal cell dendrites are located (Fig. $3 A-C$ ). Regions of CA1 from MAMexposed rats containing normotopic cells exhibited a pattern of Kv4.2 staining similar to controls (Fig. 3D,F). Heterotopic pyramidal neurons in the sections from MAM-exposed animals exhibited markedly reduced Kv4.2 staining in adjoining regions of stratum radiatum and oriens (Fig. 3). Moderate levels of Kv4.2 mRNA and protein can be found in all neocortical pyramidal cell regions (data not shown) (Serodio and Rudy, 1998). Taken together, our results suggest that Kv4.2 subunit expression is extremely low in regions of hippocampus containing heterotopic neurons.

\section{Potassium currents in heterotopic neurons}

In addition to the enhanced seizure susceptibility reported in rats with MAM-induced malformations (Baraban and Schwartzkroin, 1996; Germano et al., 1996; Germano and Sperber, 1997; Chevassus-au-Louis et al., 1998a), malformations also exhibit a number of unusual physiological properties, including impaired long-term potentiation (Ramakers et al., 1993), enhanced excit- 

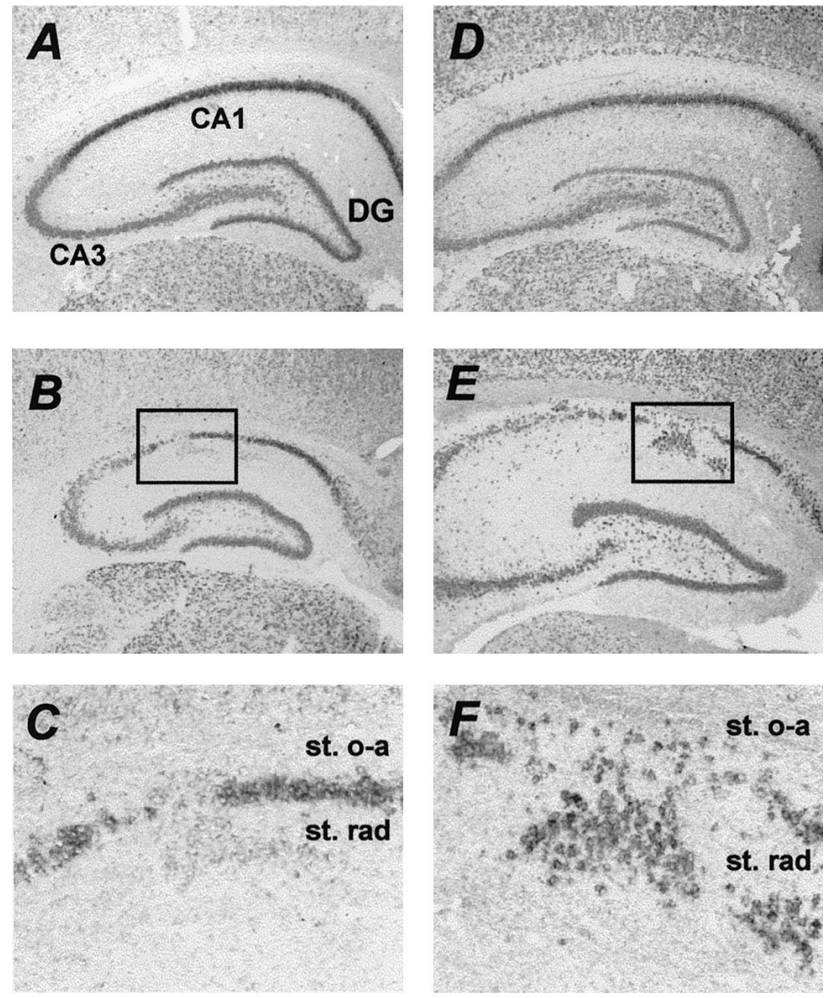

Figure 2. Expression of Kv4.2 and Kv2.1 mRNA in the rat hippocampus. $A$, Coronal hippocampal section showing Kv4.2 labeling in the CA1-CA3 pyramidal cell and dentate granule cell regions from a normal, salinetreated control rat. $B, \mathrm{Kv} 4.2$ labeling in a coronal hippocampal section from a MAM-exposed rat. $C$, Higher magnification of Kv4.2 labeling shown in $B$ (box). Note the marked reduction of Kv4.2 labeling in an area corresponding to a nodular heterotopia. $D$, Coronal hippocampal section showing Kv2.1 labeling in the CA1-CA3 pyramidal cell and dentate granule cell regions from a normal, saline-treated control rat. E, Kv2.1 labeling in a coronal hippocampal section from a MAM-exposed rat. $F$, Higher magnification of Kv2.1 labeling shown in $D$ (box). CA1, $C A 3$, Hippocampal subfields; $D G$, dentate gyrus; st. $o-a$, stratum oriens-alveus; st. rad, stratum radiatum.

ability (Baraban and Schwartzkroin, 1995), and an ability to independently generate epileptiform discharges (Baraban et al., 2000). Because the migration defect in MAM animals is induced early in neurogenesis (i.e., embryonic day 15), a developmental alteration in the intrinsic membrane properties of heterotopic neurons might be responsible for observed physiological deficits. Indeed, it has been reported that periventricular heterotopic neurons in the MAM model fire long-lasting repetitive bursts of action potentials (APs) in response to small membrane depolarizations (Sancini et al., 1998). To determine whether $\mathrm{K}^{+}$channel function is altered on hippocampal heterotopic neurons, we examined potassium currents using visualized patch-clamp recording techniques (Stuart et al., 1993). Whole-cell voltage-activated potassium current was recorded in the presence of sodium and calcium channel blockers $(1 \mu \mathrm{M}$ tetrodotoxin and $100 \mu \mathrm{M}$ cadmium, respectively). Normal CA1 pyramidal neurons display prominent voltage-activated outward currents when the membrane is depolarized beyond $-20 \mathrm{mV}$ (Spigelman et al., 1992; Klee et al., 1995). In saline-treated rats, outward currents with distinct $I_{\mathrm{K}}$ and $I_{\mathrm{A}}$ components were observed on CA1 pyramidal neurons $(n=17)$ (Fig. $4 A$ ). Using the same voltage-clamp protocol and recording conditions for slices from MAM-exposed rats, we observed outward currents on heterotopic pyramidal
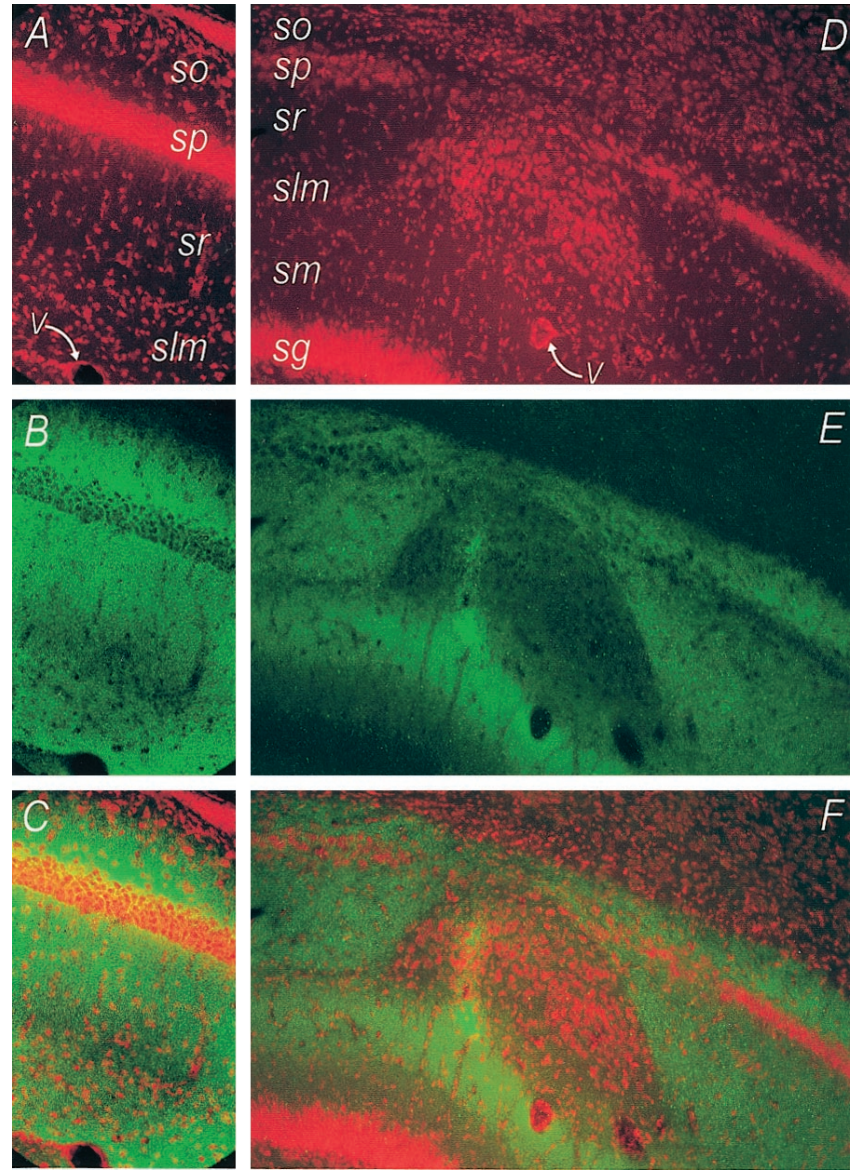

Figure 3. Expression of Kv4.2 protein in the rat hippocampus. $A$, Coronal hippocampal section showing propidium iodide (mRNA cell body stain) labeling in the CA1 pyramidal cell region from a normal, salinetreated control rat. $B, \mathrm{Kv} 4.2$ antibody staining in the same hippocampal section. $C$, Color overlay of $A$ and $B$ showing cell body staining (red $)$ and Kv4.2 localization ( green). $D-F$, Propidium iodide and Kv4.2 labeling for a coronal hippocampal section from a MAM-exposed rat. Note the absence of Kv4.2 localization (green) in the heterotopic cell region (red) in $F$. so, Stratum oriens; $s p$, stratum pyramidale; $s r$, stratum radiatum; $s l m$, stratum lacunosum-moleculare; $v$, blood vessel.

neurons with distinct delayed, rectifier-type but no evidence of fast, transient potassium currents $(n=23)$ (Fig. 4A).

The lack of functional A-type potassium current may be attributable to a general and nonspecific disruption of potassium channel development after prenatal MAM exposure. To determine whether the delayed, rectifier-type $\mathrm{K}^{+}$current component was affected by MAM treatment, we compared the kinetic properties of $I_{\mathrm{K}}$ on normal CA1 pyramidal neurons with $I_{\mathrm{K}}$ on heterotopic pyramidal neurons. The $\mathrm{K}^{+}$currents in the two types of neurons did not differ in their voltage dependence of activation. Normalized conductance-voltage relationships, calculated from respective peak current amplitudes, showed indistinguishable plots (Fig. $4 B$ ). The decay time course of $I_{\mathrm{K}}$ (Klee et al., 1995) was similar in both cell types. To calculate decay time constants, cells were held at $0 \mathrm{mV}$, hyperpolarized to $-120 \mathrm{mV}$, and the current fitted with a double exponential function (normal CA1: $\tau 1=1896.3 \pm$ $279.1 \mathrm{msec} ; \tau 2=344.8 \pm 22.0 \mathrm{msec} ; n=5$; heterotopic pyramidal neurons: $\tau 1=1894.9 \pm 221.7 \mathrm{msec} ; \tau 2=365.7 \pm 30.1 \mathrm{msec} ; n=$ $4 ; \tau 1, p=0.997$ and $\tau 2, p=0.588$; Student's $t$ test ). There were also no differences in $I_{\mathrm{K}}$ current amplitude measured at the 575 msec time point of a $600 \mathrm{msec}$ depolarizing voltage step (Fig. 4C). 
A
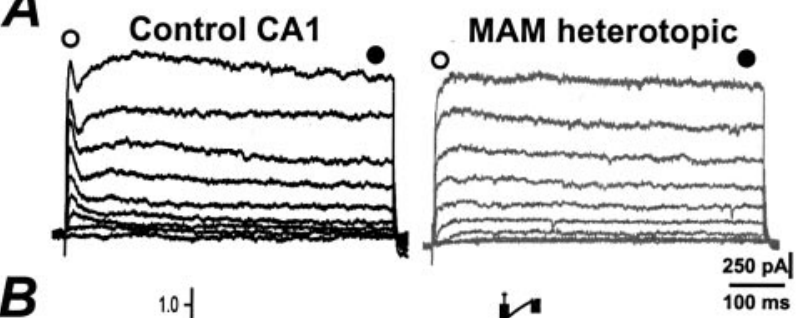

B
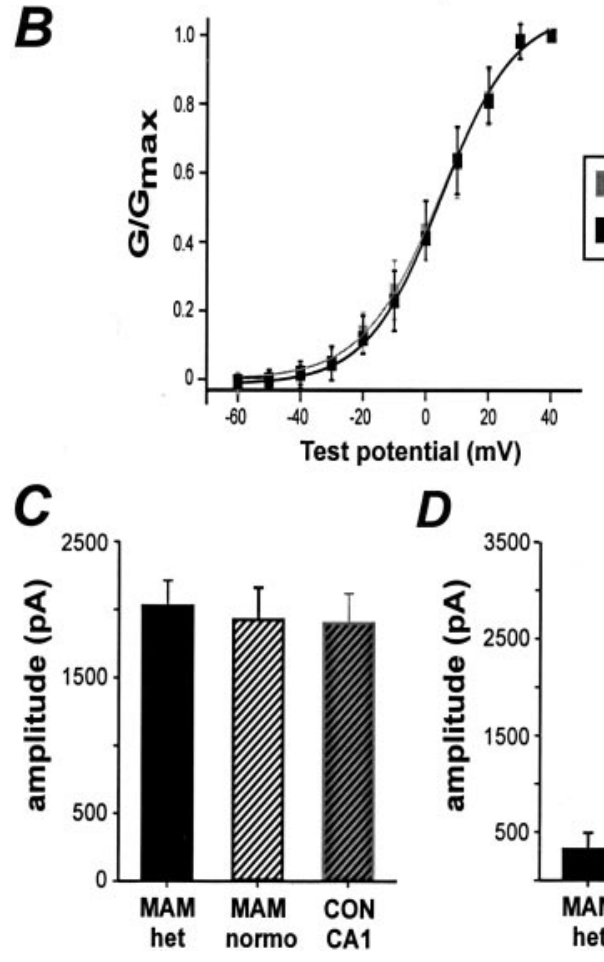

D

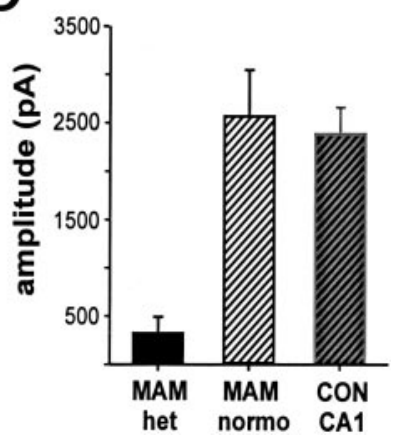

Figure 4. A-type potassium current is reduced in heterotopic pyramidal cells. $A$, Outward currents from a CA1 pyramidal neuron (Control CA1) and heterotopic pyramidal neuron (MAM heterotopic) were elicited by stepping from a holding potential of $-60 \mathrm{mV}$ to $+40 \mathrm{mV}$ in $10 \mathrm{mV}$ increments. A $150 \mathrm{msec}$ prepulse to $-110 \mathrm{mV}$ preceded each depolarizing step. Fast, transient A-type current was measured at the peak $(\bigcirc)$, and sustained, delayed, rectifier current was measured at the $575 \mathrm{msec}$ time point $(\bullet) . B, I_{\mathrm{K}}$ activation curves for CA1 pyramidal $(C O N ; n=13)$ and heterotopic pyramidal $(M A M ; n=7)$ neurons. Chord conductance $\left(G_{\mathrm{K}}\right)$ was calculated by transforming peak currents using the equation $G_{\mathrm{K}}=$ $\left.I / V-V_{\mathrm{K}}\right)$, where $I$ is the peak amplitude at a given test potential $(V)$ and $\mathrm{V}_{\mathrm{K}}$ equals the $\mathrm{K}^{+}$reversal potential. A calculated $\mathrm{K}^{+}$equilibrium potential of $-100.1 \mathrm{mV}$ was used. $G_{\mathrm{K}}$ was normalized to 1.0 by the maximum conductance $\left(G_{\max }\right)$ and plotted as the mean \pm SE versus the test potential $(\mathrm{mV})$. $C$, Plot of the peak current amplitudes for $I_{\mathrm{K}}$ on heterotopic pyramidal cells $(M A M$ het), normotopic pyramidal cells ( $M A M$ normo), and CA1 pyramidal cells $(C O N C A 1)$. Plotted are means $\pm \mathrm{SE}$. $D$, Same for $I_{\mathrm{A}}$.

In contrast, as predicted from our $\mathrm{K}^{+}$channel expression studies, $I_{\mathrm{A}}$ was dramatically decreased for heterotopic neurons in comparison with normal CA1 pyramidal neurons from saline-treated rats (Fig. 4D). To determine whether normotopic CA1 pyramidal neurons in MAM rats also showed altered $\mathrm{K}^{+}$currents, we analyzed peak current amplitudes for $I_{\mathrm{K}}$ and $I_{\mathrm{A}}$ in these cells. Normotopic pyramidal neurons exhibited mRNA expression profiles similar to normal CA1 pyramidal neurons, and as expected, $I_{\mathrm{K}}$ and $I_{\mathrm{A}}$ current amplitudes were comparable between these two cell types $(n=6)$ (Fig. $4 C, D)$. Activation curves and time constants of decay were also similar to those values reported for normal CA1 pyramidal neurons (data not shown).
A L-M interneuron
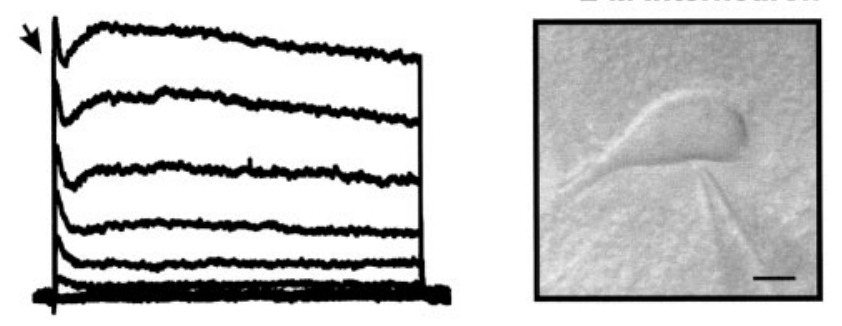

B

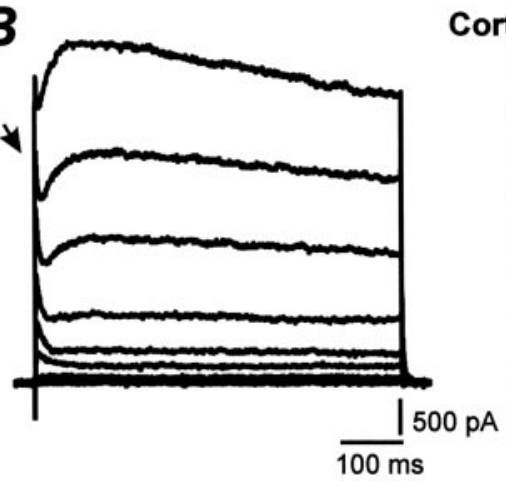

Cortex (V-VI) pyramidal

Figure 5. Potassium current function in neocortical pyramidal cells and hippocampal interneurons. $A$, Representative whole-cell voltage-clamp recording from a visually identified (IR-DIC image, right panel) interneuron in the stratum lacunosum-moleculare region of a control hippocampal slice. Note the presence of $I_{\mathrm{A}^{-}}$and $I_{\mathrm{K}^{-}}$-type outward potassium currents. Voltage-step protocol is same as in Figure 4. B, Same for a layer V-VI pyramidal neuron in a control cortical slice. Scale bar (shown in $A$ ): $8 \mu \mathrm{m}$.

We also examined $\mathrm{K}^{+}$current function in neocortical slices (coronal sections, somatosensory cortex) from saline-treated rats, because previous work suggested a neocortical origin for hippocampal heterotopic neurons (Chevassus-au-Louis et al., 1998b,c). Outward currents with distinct delayed, rectifier-type and fast, transient-type components were observed on layer V-V I pyramidal neurons $(n=11)$ (Fig. $5 B)$. Interneurons located within hippocampal heterotopia in slices from MAM rats $(n=7$; data not shown) or in stratum lacunosum-moleculare in slices from control saline-treated animals $(n=5)$ (Fig. $5 A)$ were also found to have prominent $I_{\mathrm{A}^{-}}$and $I_{\mathrm{K}^{-}}$type outward currents. Although heterotopia can contain parvalbumin-expressing, presumably GABAergic, interneurons and are composed of pyramidallike cells with a putative neocortical origin (Chevassus-au-Louis et al., 1998b,c), our findings suggest a distinct potassium current profile (e.g., very little $I_{\mathrm{A}}$ ) for hippocampal heterotopic neurons.

4-Aminopyridine (4-AP) blocks $I_{\mathrm{A}}$-type current in normal CA1 pyramidal neurons and tetraethylammonium chloride (TEA) blocks $I_{\mathrm{K}}$ (Rudy, 1988). Therefore, we used these drugs to examine the pharmacological properties of $\mathrm{K}^{+}$currents. If heterotopic neurons express $I_{\mathrm{K}}$, but little or no $I_{\mathrm{A}}$, we expected these cells to be TEA sensitive and relatively 4-AP insensitive. At a concentration of $20 \mathrm{~mm}$, TEA inhibited $I_{\mathrm{K}}$, leaving a small TEAinsensitive fast, transient current component $(n=8)($ Fig. $6 A) . I_{\mathrm{K}}$ was also inhibited by $20 \mathrm{~mm}$ TEA on heterotopic neurons, but very little $I_{\mathrm{A}}$ was observed during perfusion with this drug $(n=$ 11) (Fig. 6A). At a concentration of $10 \mathrm{~mm}, 4-\mathrm{AP}$ completely inhibited $I_{\mathrm{A}}$ on normal CA1 pyramidal neurons $(n=7)$ (Fig. $6 B$, left). This same drug concentration had a markedly reduced effect on heterotopic pyramidal neurons $(n=8)$ (Fig. $6 B$, right). Thus, 

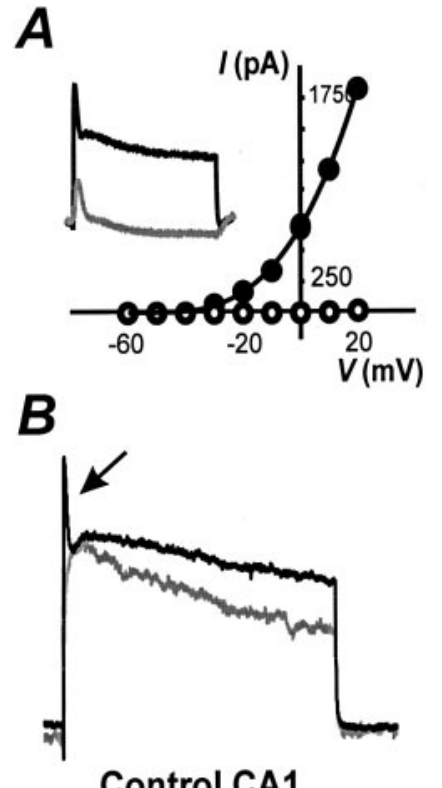

\section{Control CA1}

Figure 6. Sensitivity of outward currents to TEA and 4-AP. A, TEA (20 $\mathrm{mM}$ ) blocked the sustained, delayed, rectifier potassium current on CA1 pyramidal (Control CA1) and heterotopic pyramidal (MAM het) neurons (inset, top left). Representative traces are shown for each cell before (black) and $\sim 5$ min after TEA application ( gray). $I-V$ plots are shown for each cell before $(\bullet)$ and after TEA $(\bigcirc)$; control CA1 cell plot is on left, and MAM heterotopic cell plot is on right. B, 4-AP (10 mM) selectively blocks the fast, transient potassium current on CA1 pyramidal neurons (arrow, Control CA1, left panel). 4-AP had little effect on heterotopic pyramidal neurons (MAM het, right panel). Representative traces are shown for each cell before (black) and $\sim 5$ min after 4-AP application (gray).

marked reductions in a potassium current, with gating and pharmacological properties of $I_{\mathrm{A}}$, is a prominent feature of hippocampal heterotopic neurons and appears to distinguish them from normal CA1 pyramidal cells, interneurons, and cortical pyramidal cells.

\section{Firing properties of heterotopic neurons}

Heterologous expression of Kv4.2 subunits in cultured cells results in a rapidly inactivating, 4-AP-sensitive A-type outward $\mathrm{K}^{+}$ current (Baldwin et al., 1992; Serodio et al., 1994). In normal hippocampus, Kv4.2 subunits are prominently expressed on somata and dendrites of CA1 pyramidal neurons where they are believed to underlie an A-type current that contributes to control of action potential firing frequency, spike repolarization, and integration of signals received on dendrites (Hoffman et al., 1997; Martina et al., 1998; Serodio and Rudy, 1998). We therefore examined the firing properties of heterotopic neurons lacking Kv4.2 and a functional A-type potassium current. Because heterotopic neurons functionally integrate into the hippocampal circuit (Chevassus-au-Louis et al., 1998a; Baraban et al., 2000) and disrupt or displace a hippocampal region normally occupied by CA1 pyramidal cells (Fig. 1), we compared their properties with those of CA1 pyramidal cells from saline-treated animals. In current-clamp recordings, heterotopic neurons had resting membrane potential (RMP) values $(-64.5 \pm 0.9 \mathrm{mV} ; n=17)$ that could not be distinguished from those of age-matched CA1 pyramidal neurons (RMP, $-65 \pm 0.4 \mathrm{mV} ; n=27 ; p=0.57$, Student's $t$ test) recorded in slices from saline-treated rats. Measurement of membrane time constants also failed to reveal sig-
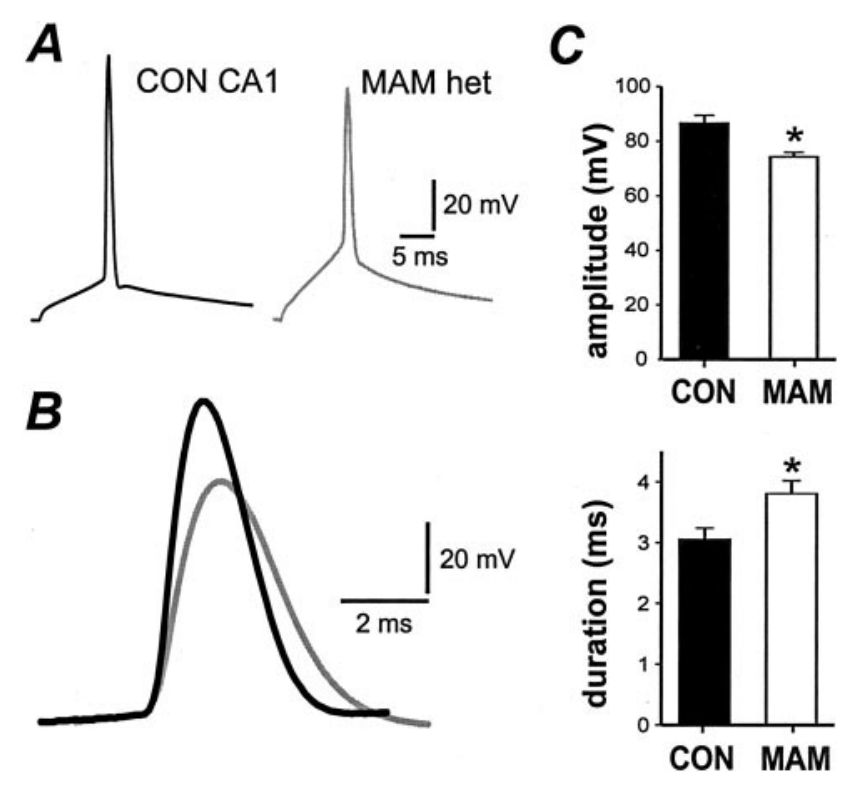

Figure 7. Action potential properties of CA1 and heterotopic pyramidal neurons. $A$, A single action potential was elicited in CA1 pyramidal (CON $C A 1)$ and heterotopic pyramidal (MAM het) neurons by a brief $10 \mathrm{msec}$ depolarizing current injection. $B$, The properties of a single action potential are not identical in these two cell types. Superimposed action potentials are shown at an expanded time-scale for a representative CA1 pyramidal (black trace) and heterotopic pyramidal (gray trace) neuron. $C$, Plots of action potential amplitude and duration for all CA1 pyramidal neurons (black bars) and heterotopic pyramidal neurons (white bars). Plotted are means $\pm \mathrm{SE}$; asterisk denotes significance taken as $p<0.05$, Student's $t$ test.

nificant differences (CA1 pyramidal: $19.1 \pm 1.0 \mathrm{msec}, n=19$; heterotopic pyramidal: $21.8 \pm 4.2, n=12 ; p=0.53$ ). In contrast, further analysis of membrane properties revealed differences in AP amplitude, duration, and firing frequency. First, heterotopic pyramidal neurons exhibited action potentials with significantly smaller peak amplitudes (Figs. 7A-C). These differences in AP amplitude were associated with higher input resistances for heterotopic neurons (CA1 pyramidal: $145.3 \pm 8.9 \mathrm{M} \Omega, n=14$; heterotopic pyramidal: $313.1 \pm 56.1 \mathrm{M} \Omega, n=10 ; p=0.14$ ). Second, consistent with a lack of functional A-type $\mathrm{K}^{+}$current (Fig. 4), analysis of action potential duration revealed that heterotopic cells had longer AP durations than those of age-matched CA1 pyramidal neurons (Figs. $7 B, C$ ). Third, both normotopic CA1 and heterotopic pyramidal neurons fired a single action potential in response to brief depolarizing current pulses (Fig. $7 A$ ). The amount of current injection required to elicit a single action potential during a brief $5 \mathrm{msec}$ pulse was slightly higher for heterotopic cells (CA1 pyramidal: $232 \mathrm{pA}, n=23$; heterotopic pyramidal: $267 \mathrm{pA}, n=7 ; p=0.123)$. However, in response to long depolarizing current pulses, distinct differences in firing activity could be observed. During a long membrane depolarization, normal CA1 pyramidal cells fire repetitively at a decrementing frequency (i.e., spike frequency adaptation), whereas heterotopic cells fired repetitively with much less adaptation (Fig. 8A,D). Similarly, heterotopic pyramidal neurons fired at significantly higher frequencies than age- and RMP-matched control CA1 pyramidal cells under all current pulse durations (100-900 msec) (Fig. 8B) and at all levels of current injection (100-1000 pA) (Fig. $8 D$ ) tested. These qualitative differences in firing frequency were further confirmed by (1) plotting the instantaneous firing frequency versus latency (Fig. 8C), (2) using quantitative analysis of 

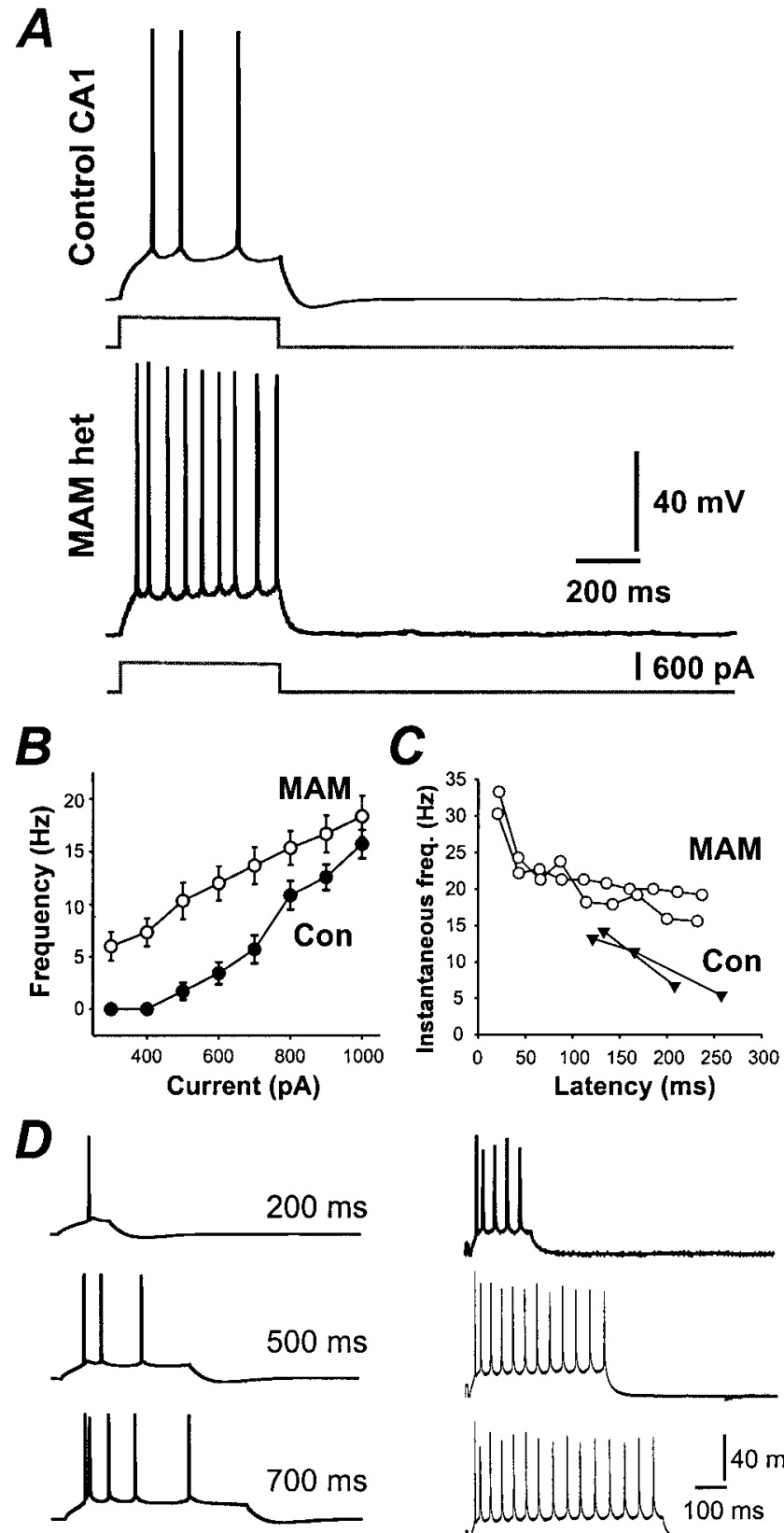

Control CA1

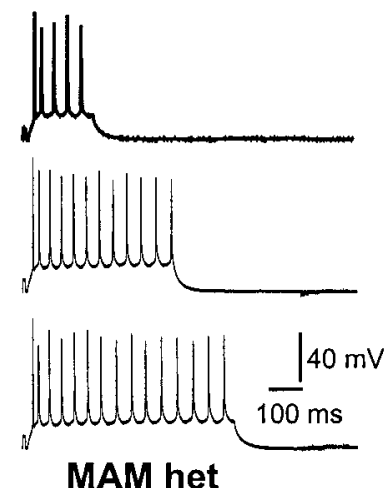

Figure 8. Firing properties of CA1 and heterotopic pyramidal neurons. $A$, Representative traces of a CA1 pyramidal neuron (Control CA1) and heterotopic pyramidal neuron (MAM het) recorded in current-clamp during a $500 \mathrm{msec}$ depolarizing current injection $(600 \mathrm{pA}) . B$, Plot of the firing frequency versus amount of current injected for all CA1 pyramidal $(C o n,-)$ and heterotopic pyramidal $(M A M, \bigcirc)$ neurons. Plotted are means $\pm \mathrm{SE}$. $C$, Plot of the instantaneous firing frequency versus latency for two representative CA1 pyramidal $(\mathrm{Con}, \mathbf{0})$ and heterotopic pyramidal $(M A M$ het,$\bigcirc)$ neurons. $D$, Representative traces of a CA1 pyramidal neuron (Control CA1) and a heterotopic pyramidal neuron (MAM het) during long depolarizing current injections (600-700 pA).

spike frequency adaptation time constants (Buckmaster et al., 1993) (CA1 pyramidal: $118.2 \pm 32.4 \mathrm{msec}$; heterotopic pyramidal: $306.9 \pm 75.8 \mathrm{msec} ; p=0.041$ for a $0.5 \mathrm{nA}$ current pulse), and (3) using measurements of firing frequency (CA1 pyramidal: $7.1 \pm$ $0.6 \mathrm{~Hz}, n=10$; heterotopic pyramidal: $20.3 \pm 1.6 \mathrm{~Hz}, n=9, p<$ $0.001)$. Taken together, the observed differences demonstrate the neuronal hyperexcitability of heterotopic neurons in the MAM model of cortical malformations and epilepsy.

\section{DISCUSSION}

Clinical and experimental studies support a role for malformed brain tissue in the development of epilepsy (Palmini et al., 1991a,b, 1995; Aicardi, 1994; Germano et al., 1996; Chevassusau-Louis et al., 1999; Baraban et al., 2000; Palmini, 2000). In fact, recent studies suggest that heterotopias and abnormal cytoarchitecture are the most common neuropathological finding in children with medically intractable epilepsy treated surgically (Duchowny et al., 1992; Brannstrom et al., 1996). Unfortunately, very little is known about potential cellular causes of hyperexcitability in regions of malformations. Here we used molecular and electrophysiological approaches to demonstrate that a potassium channel subunit is lacking on heterotopic neurons in an animal model of cortical malformations.

We have shown, using in situ hybridization, that Shab (Kv2.1) potassium channel subunits exhibit similar patterns of expression in normal hippocampus and malformed hippocampus from MAM-exposed rats. By contrast, both in situ hybridization and immunohistochemical experiments showed that levels of Shal (Kv4.2) subunits were markedly reduced within malformed brain regions. Although this subunit is prominently expressed in somatic and dendritic regions of normotopic pyramidal neurons in the MAM-exposed rat brain, expression on heterotopic pyramidal neurons is absent or barely detectable (Figs. $2 C, 3 F$ ). Potassium channels are important regulators of electrical signaling in the brain and act to limit the excitability of individual neurons (Pongs, 1999). Thus, it is not surprising that an alteration in $\mathrm{K}^{+}$ channel expression in the MAM model could potentially contribute to hyperexcitability and a predisposition toward seizure activity. In humans, mutations in the KCNQ2 and KCNQ3 potassium channel subunits result in benign familial neonatal convulsions (BFNC), a rare form of pediatric epilepsy (Biervert et al., 1998; Singh et al., 1998). In mice, a null mutation of the Kv1.1 Shaker-type voltage-gated potassium channel leads to frequent, often fatal, generalized seizures (Smart et al., 1998). Point mutations in Kv1.1 channels are also associated with increased epilepsy risk in humans (Zuberi et al., 1999). The interesting observation in the MAM model of cortical malformations (a non-idiopathic epilepsy phenotype) is that abnormal Kv4.2 potassium channel expression appears to be restricted to heterotopic neurons. In both the human condition of BFNC and Kv1.1 knockout mice, altered potassium channel expression is global (e.g., the mutation is presumably present in neurons throughout the CNS). In MAM rats, normotopic pyramidal neurons directly adjacent to heterotopic cells express Kv4.2 transcripts (and have functional A-type currents) consistent with the suggestion that nodular heterotopia, with its neuron-specific loss of Kv4.2, are potential sites of hyperexcitability in these experimental animals. Indeed, previous work has demonstrated that isolated nodular heterotopia in hippocampal slices from MAM-exposed rats exposed to convulsant agents (either bicuculline or 4-AP) are capable of independent seizure generation (Baraban et al., 2000). Moreover, intraoperative recordings from human heterotopia also suggest that these malformed brain regions can act as "seizure foci" (Palmini et al., 1995; Otsubo et al., 1997).

A-type potassium channels, based on expression of Shal-related (Kv4) genes, are prominent in the somatodendritic membranes of many mammalian neurons, including hippocampal pyramidal neurons, hippocampal interneurons, and neocortical pyramidal 
cells (Serodio et al., 1994). These channels activate at subthreshold membrane potentials, inactivate rapidly, and are sensitive to 4-AP but largely insensitive to TEA. In many types of neurons, A-type channels modulate neuronal firing frequency, spike repolarization, and action potential waveform (Byrne, 1980; Llinas, 1988; Rudy, 1988; McCormick and Huguenard, 1992). By limiting neuronal excitability, A-type currents are an endogenous mechanism designed to prevent neuronal hyperexcitability. Observed differences in the firing properties of heterotopic neurons (e.g., input resistance, spike amplitude, and a slowing of the rising phase of the action potential) suggest that reduced Kv4.2 expression, although clearly important, may not be the only abnormality associated with dysplastic neurons. Although our studies do not rule out these additional potentially defective mechanisms (including other ion channels or postsynaptic receptors), a lack of functional A-type potassium channels on heterotopic neurons would be expected to directly contribute to the abnormal cellular physiology and network hyperexcitability observed in the MAM model of non-idiopathic, malformation-associated epilepsy.

In the MAM model of cortical malformations, heterotopic hippocampal neurons make aberrant connections with neocortical structures (Chevassus-au-Louis et al., 1998b). This synaptic defect could result in the rapid spread of burst discharge activity between hippocampal and cortical structures, but it does not explain the intrinsic ability of heterotopic neurons to generate burst-like firing patterns (Baraban and Schwartzkroin, 1995; Sancini et al., 1998). Similarly, expression of the GluR2 "flip" subunit of the AMPA receptor is increased in heterotopic cell regions, but a hyperexcitability linked to an excitatory/inhibitory neurotransmission imbalance has not been reported for MAM-exposed animals (Baraban and Schwartzkroin, 1996; Chevassus-au-Louis et al., 1998b,c; Rafiki et al., 1998). In the MAM model, many periventricular heterotopic neurons (a more heterogeneous cell population than the nodular hippocampal heterotopia studied here) exhibit "excessive bursting" behavior consisting of an unusually long train of action potentials (Sancini et al., 1998). This type of firing behavior can result from a defect in the $\mathrm{K}^{+}$mediated control of intrinsic membrane excitability, and consistent with this hypothesis, we reported that a slight increase in extracellular $\mathrm{K}^{+}$concentration leads to epileptiform activity in tissue slices from these animals (Baraban and Schwartzkroin, 1995). On the basis of these previous observations and the results reported here, we hypothesize that abnormal $\mathrm{K}^{+}$channel expression in heterotopic neurons could lead to excessive burst firing and epileptogenesis in regions of brain malformations. This hypothesis remains to be tested in additional animal studies as well as in human tissue obtained during surgery for intractable epilepsy associated with a brain malformation.

As discussed, it is not yet known whether reductions in Kv4.2 channel expression observed in the MAM model occur in humans with cortical malformations and epilepsy. However, our findings have important implications for understanding how malformed neurons might contribute to a hyperexcitable phenotype, independent of the type of malformation. First, clinical data clearly demonstrate structural alterations (increased neurofilament and microtubule-associated proteins) and unusual accumulation of glial markers (GFAP and vimentin) in individual dysplastic neurons. How these structural changes lead to neuronal hyperexcitability, however, is not clear. In contrast, our studies demonstrating abnormal ion channel expression and function in individual heterotopic neurons in the MAM model suggest at least one plausible mechanism for hyperexcitability. Because al- tered Kv4.2 expression may be a common feature of the malformed brain, we suggest that similar studies should be performed in human tissue (or other animal models of cortical malformations). Second, identification of a potentially epileptogenic defect in a clinically relevant rodent epilepsy model could lead to the testing of novel therapeutic approaches. For example, it would be of great interest to determine whether insertion of a transgene encoding Kv4.2 into heterotopic neurons would restore normal cellular firing activity and, perhaps, reverse the predisposition toward seizure activity observed in MAM-exposed rats. In general, the identification of precise molecular abnormalities associated with specific epileptic phenotypes sets the stage for further efforts to design treatments targeted toward reversing these defects.

\section{REFERENCES}

Aicardi J (1994) The place of neuronal migration abnormalities in child neurology. Can J Neurol Sci 21:185-193.

Andermann F (2000) Cortical dysplasias and epilepsy: a review of the architectonic, clinical, and seizure patterns. Adv Neurol 84:479-496.

Annegers JF (1994) Epidemiology and genetics of epilepsy. Neurol Clin 12:15-29.

Babb TL, Ying Z, Hadam J, Penrod C (1998) Glutamate receptor mechanisms in human epileptic dysplastic cortex. Epilepsy Res 32:24-33.

Baldwin TJ, Isacoff E, Li M, Lopez GA, Sheng M, Tsaur ML, Yan YN, Jan LY (1992) Elucidation of biophysical and biological properties of voltage-gated potassium channels. Cold Spring Harb Symp Quant Biol 57:491-499.

Baraban SC, Schwartzkroin PA (1995) Electrophysiology of CA1 pyramidal neurons in an animal model of neuronal migration disorders: prenatal methylazoxymethanol treatment. Epilepsy Res 22:145-156.

Baraban SC, Schwartzkroin PA (1996) Flurothyl seizure susceptibility in rats following prenatal methylazoxymethanol treatment. Epilepsy Res 23:189-194

Baraban SC, Wenzel HJ, Hochman DW, Schwartzkroin PA (2000) Characterization of heterotopic cell clusters in the hippocampus of rats exposed to methylazoxymethanol in utero. Epilepsy Res 39:87-102.

Bardosi A, Ambach G, Hann P (1987) The angiogenesis of the microencephalic rat brains caused by methylazoxymethanol acetate. III. Internal angioarchitecture of cortex. Acta Neuropathol 75:85-91.

Biervert C, Schroeder BC, Kubisch C, Berkovic SF, Propping P, Jentsch TJ, Steinlein OK (1998) A potassium channel mutation in neonatal human epilepsy. Science 279:403-406.

Brannstrom T, Silvenius H, Olivecrona M (1996) The range of disorders of cortical organisation in surgically treated epilepsy patients. New York: Lippincott-Raven.

Buckmaster PS, Strowbridge BW, Schwartzkroin PA (1993) A comparison of rat hippocampal mossy cells and CA3c pyramidal cells. J Neurophysiol 70:1281-1299.

Byrne JH (1980) Analysis of ionic conductance mechanisms in motor cells mediating inking behavior in Aplysia californica. J Neurophysiol 43:630-650.

Chan S, Chin SS, Nordli DR, Goodman RR, DeLaPaz RL, Pedley TA (1998) Prospective magnetic resonance imaging identification of focal cortical dysplasia, including the non-balloon cell subtype. Ann Neurol 44:749-757.

Chevassus-au-Louis N, Ben-Ari Y, Vergnes M (1998a) Decreased seizure threshold and more rapid rate of kindling in rats with cortical malformation induced by prenatal treatment with methylazoxymethanol. Brain Res 812:252-255.

Chevassus-au-Louis N, Congar P, Represa A, Ben-Ari Y, Gaiarsa JL (1998b) Neuronal migration disorders: heterotopic neocortical neurons in CA1 provide a bridge between the hippocampus and the neocortex. Proc Natl Acad Sci USA 95:10263-10268.

Chevassus-au-Louis N, Rafiki A, Jorquera I, Ben-Ari Y, Represa A (1998c) Neocortex in the hippocampus: an anatomical and functional study of CA1 heterotopias after prenatal treatment with methylazoxymethanol in rats. J Comp Neurol 394:520-536.

Chevassus-au-Louis N, Baraban SC, Gaiarsa JL, Ben-Ari Y (1999) Cortical malformations and epilepsy: new insights from animal models. Epilepsia 40:811-821.

Cooper EC, Jan LY (1999) Ion channel genes and human neurological disease: recent progress, prospects, and challenges. Proc Natl Acad Sci USA 96:4759-4766.

Cooper EC, Milroy A, Jan YN, Jan LY, Lowenstein DH (1998) Presynaptic localization of Kv1.4-containing A-type potassium channels near excitatory synapses in the hippocampus. J Neurosci 18:965-974.

Du J, Tao-Cheng JH, Zerfas P, McBain CJ (1998) The K+ channel, Kv2.1, is apposed to astrocytic processes and is associated with inhib- 
itory postsynaptic membranes in hippocampal and cortical principal neurons and inhibitory interneurons. Neuroscience 84:37-48.

Dubeau F, Tampieri D, Lee N, Andermann E, Carpenter S, Leblanc R, Olivier A, Radtke R, Villemure JG, Andermann F (1995) Periventricular and subcortical nodular heterotopia. A study of 33 patients. Brain 118:1273-1287.

Duchowny M, Levin B, Jayakar P, Resnick T, Alvarez L, Morrison G, Dean P (1992) Temporal lobectomy in early childhood. Epilepsia 33:298-303.

Germano IM, Sperber EF (1997) Increased seizure susceptibility in adult rats with neuronal migration disorders. Brain Res 777:219-222.

Germano IM, Zhang YF, Sperber EF, Moshe SL (1996) Neuronal migration disorders increase susceptibility to hyperthermia-induced seizures in developing rats. Epilepsia 37:902-910.

Hoffman DA, Magee JC, Colbert CM, Johnston D (1997) K+ channel regulation of signal propagation in dendrites of hippocampal pyramidal neurons. Nature 387:869-875.

Johnston MV, Grzanna R, Coyle JT (1979) Methylazoxymethanol treatment of fetal rats results in abnormally dense noradrenergic innervation of neocortex. Science 203:369-371.

Klee R, Ficker E, Heinemann U (1995) Comparison of voltagedependent potassium currents in rat pyramidal neurons acutely isolated from hippocampal regions CA1 and CA3. J Neurophysiol 74:1982-1995.

Kuzniecky RI (1994) Magnetic resonance imaging in developmental disorders of the cerebral cortex. Epilepsia 35:S44-56.

Llinas RR (1988) The intrinsic electrophysiological properties of mammalian neurons: insights into central nervous system function. Science 242:1654-1664.

Maletic-Savatic M, Lenn NJ, Trimmer JS (1995) Differential spatiotemporal expression of $\mathrm{K}+$ channel polypeptides in rat hippocampal neurons developing in situ and in vitro. J Neurosci 15:3840-3851.

Martina M, Schultz JH, Ehmke H, Monyer H, Jonas P (1998) Functional and molecular differences between voltage-gated $\mathrm{K}+$ channels of fastspiking interneurons and pyramidal neurons of rat hippocampus. J Neurosci 18:8111-8125.

McCormick DA, Huguenard JR (1992) A model of the electrophysiological properties of thalamocortical relay neurons. J Neurophysiol 68:1384-1400.

Mischel PS, Nguyen LP, Vinters HV (1995) Cerebral cortical dysplasia associated with pediatric epilepsy. Review of neuropathologic features and proposal for a grading system. J Neuropathol Exp Neurol 54:137-153.

Murakoshi H, Trimmer JS (1999) Identification of the Kv2.1 K+ channel as a major component of the delayed rectifier $\mathrm{K}+$ current in rat hippocampal neurons. J Neurosci 19:1728-1735.

Otsubo H, Steinlin M, Hwang PA, Sharma R, Jay V, Becker LE, Hoffman HJ, Blaser S (1997) Positive epileptiform discharges in children with neuronal migration disorders. Pediatr Neurol 16:23-31.

Palmini A (2000) Disorders of cortical development. Curr Opin Neurol 13:183-192.

Palmini A, Andermann F, Olivier A, Tampieri D, Robitaille Y (1991a) Focal neuronal migration disorders and intractable partial epilepsy: results of surgical treatment. Ann Neurol 30:750-757.

Palmini A, Andermann F, Olivier A, Tampieri D, Robitaille Y, Andermann E, Wright G (1991b) Focal neuronal migration disorders and intractable partial epilepsy: a study of 30 patients. Ann Neurol 30:741-749.

Palmini A, Gambardella A, Andermann F, Dubeau F, da Costa JC, Olivier A, Tampieri D, Gloor P, Quesney F, Andermann E (1995) Intrinsic epileptogenicity of human dysplastic cortex as suggested by corticography and surgical results. Ann Neurol 37:476-487.

Pongs O (1999) Voltage-gated potassium channels: from hyperexcitability to excitement. FEBS Lett 452:31-35.
Rafiki A, Chevassus-au-Louis N, Ben-Ari Y, Khrestchatisky M, Represa A (1998) Glutamate receptors in dysplasic cortex: an in situ hybridization and immunohistochemistry study in rats with prenatal treatment with methylazoxymethanol. Brain Res 782:142-152.

Ramakers GM, Urban IJ, De Graan PN, Di Luca M, Cattabeni F, Gispen WH (1993) The impaired long-term potentiation in the CA1 field of the hippocampus of cognitive deficient microencephalic rats is restored by D-serine. Neuroscience 54:49-60.

Rudy B (1988) Diversity and ubiquity of K channels. Neuroscience 25:729-749.

Sancini G, Franceschetti S, Battaglia G, Colacitti C, Di Luca M, Spreafico R, Avanzini G (1998) Dysplastic neocortex and subcortical heterotopias in methylazoxymethanol-treated rats: an intracellular study of identified pyramidal neurones. Neurosci Lett 246:181-185.

Scheibel AB, Conrad AS (1993) Hippocampal dysgenesis in mutant mouse and schizophrenic man: is there a relationship? Schizophr Bull 19:21-33.

Serodio P, Kentros C, Rudy B (1994) Identification of molecular components of A-type channels activating at subthreshold potentials. J Neurophysiol 72:1516-1529.

Serodio P, Rudy B (1998) Differential expression of Kv4 K+ channel subunits mediating subthreshold transient $\mathrm{K}+$ (A-type) currents in rat brain. J Neurophysiol 79:1081-1091.

Sheng M, Tsaur ML, Jan YN, Jan LY (1992) Subcellular segregation of two A-type $\mathrm{K}+$ channel proteins in rat central neurons. Neuron 9:271-284.

Singh NA, Charlier C, Stauffer D, DuPont BR, Leach RJ, Melis R, Ronen GM, Bjerre I, Quattlebaum T, Murphy JV, McHarg ML, Gagnon D, Rosales TO, Peiffer A, Anderson VE, Leppert M (1998) A novel potassium channel gene, KCNQ2, is mutated in an inherited epilepsy of newborns. Nat Genet 18:25-29.

Singh SC (1977) Ectopic neurones in the hippocampus of the postnatal rat exposed to methylazoxymethanol during foetal development. Acta Neuropathol (Berl) 40:111-116.

Smart SL, Lopantsev V, Zhang CL, Robbins CA, Wang H, Chiu SY, Schwartzkroin PA, Messing A, Tempel BL (1998) Deletion of the $\mathrm{K}(\mathrm{V}) 1.1$ potassium channel causes epilepsy in mice. Neuron 20:809-819.

Spigelman I, Z hang L, Carlen PL (1992) Patch-clamp study of postnatal development of CA1 neurons in rat hippocampal slices: membrane excitability and K+ currents. J Neurophysiol 68:55-69.

Stuart GJ, Dodt HU, Sakmann B (1993) Patch-clamp recordings from the soma and dendrites of neurons in brain slices using infrared video microscopy. Pflügers Arch 423:511-518.

Trottier S, Evrard B, Biraben A, Chauvel P (1994) Altered patterns of catecholaminergic fibers in focal cortical dysplasia in two patients with partial seizures. Epilepsy Res 19:161-179.

Whiting S, Duchowny M (1999) Clinical spectrum of cortical dysplasia in childhood: diagnosis and treatment issues. J Child Neurol 14:759-771.

Williams S, Samulack DD, Beaulieu C, Lacaille J-C (1994) Membrane properties and synaptic responses of interneurons located near the stratum lacunosum-moleculare/radiatum border of area CA1 in wholecell recordings from rat hippocampal slices. J Neurophysiol 71:2217-2235.

Yurkewicz L, Valentino KL, Floeter MK, Fleshman Jr JW, Jones EG (1984) Effects of cytotoxic deletions of somatic sensory cortex in fetal rats. Somatosens Res 1:303-327.

Zuberi SM, Eunson LH, Spauschus A, De Silva R, Tolmie J, Wood NW, McWilliam RC, Stephenson JP, Kullmann DM, Hanna MG (1999) A novel mutation in the human voltage-gated potassium channel gene (Kv1.1) associates with episodic ataxia type 1 and sometimes with partial epilepsy. Brain 122:817-825. 